\title{
Effects of benzene and several pharmaceuticals on the growth and microcystin production in Microcystis aeruginosa PCC 7806
}

\author{
Laura Ceballos-Laita, Laura Calvo, María Teresa Bes, María F. Fillat and María Luisa Peleato* \\ Department of Biochemistry and Molecular and Cellular Biology, and the Institute for Biocomputation and \\ Physics of Complex Systems (BIFI), University of Zaragoza, Pedro Cerbuna 12, 50009-Zaragoza, Spain. \\ * Corresponding author: mpeleato@unizar.es
}

Received: 16/12/2013 Accepted: 02/02/2015

\begin{abstract}
Effects of benzene and several pharmaceuticals on the growth and microcystin production in Microcystis aeruginosa PCC 7806

Currently, the presence of several pharmaceuticals and other organic compounds called 'emerging' contaminants has increased in water bodies. These compounds do not need to persist in the environment to cause negative effects because they are continuously introduced. Hence, assessing the effects of these compounds on aquatic ecosystems is essential. Therefore, the aim of the present study was to analyse the effects of several emerging contaminants (ibuprofen, atenolol, diclofenac and paracetamol) and benzene on Microcystis aeruginosa PCC 7806 growth and toxicity. For this purpose, the growth and intracellular microcystin concentration in M. aeruginosa PCC 7806 were measured in presence of the four emerging contaminants and benzene. The growth rate was estimated by chlorophyll $a$ concentration, and no relevant changes were found. Changes in the expression of the operon $m c y$ were examined by semi-quantitative RT-PCR. Intracellular microcystin production was determined using a MicroCystest ${ }^{\circledR}$ kit, and no changes were observed compared to control cells. Thus, the tested concentrations of the contaminants analysed in this study do not have a significant effect on microcystin production in this strain under laboratory conditions.
\end{abstract}

Key words: Microcystin-LR, emerging contaminants, $m c y D$.

\section{RESUMEN}

Efecto del benceno y algunos fármacos en el crecimiento y producción de microcistina en Microcystis aeruginosa PCC 7806

El objetivo del presente estudio ha sido analizar el efecto del benceno y de algunos de los contaminantes emergentes más abundantes como el ibuprofeno, atenolol, diclofenac y paracetamol sobre el crecimiento de una cianobacteria toxica, Microcystis aeruginosa PCC7806, y, su producción de microcistina. Con este propósito, se determinó el crecimiento y la concentración de microcistina intracelular en $\mathrm{M}$. aeruginosa cuando ésta se encontraba en presencia de los fármacos y de uno de los solventes orgánicos más comunes en nuestros ríos. El crecimiento fue estimado mediante la determinación de la cantidad de clorofila a, la cual no presentó cambios apreciables en las condiciones ensayadas. Los cambios de expresión del operon mcy se estudiaron a través del análisis del gen mcyD mediante RT-PCR semicuantitativa. La producción de

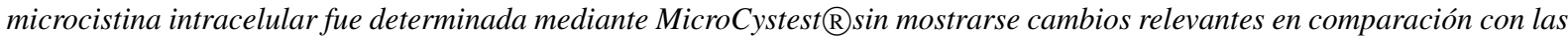
células control. Se concluye que los contaminantes analizados en este estudio no tienen un efecto significativo en la producción de microcistina, al menos, en los experimentos realizados en el laboratorio, en esta cepa, y con las dosis utilizadas.

Palabras clave: Microcistina-LR, contaminantes emergentes, mcyD. 


\section{INTRODUCTION}

The progress of society often causes changes in the environment. In river basins, many human activities that developed during the Industrial Revolution, continue to reduce the river flow and to cause influxes of many contaminants, including nutrients from untreated water, inorganic and organic fertilisers and industrial waste. These changes primarily affect phytoplankton, biofilms and bacteria, which are responsible for water quality (Vitousek et al., 1997). For decades, efforts have been focused on identifying toxic, persistent and bioaccumulative chemical contaminants. Over 100000 hazardous substances have been registered by the European Union (Fuerhacker, 2007). Nonetheless, the development of more accurate analytical methods has permitted the detection of new hazardous contaminants in water bodies; these contaminants are called emerging contaminants. Pharmaceutical compounds are causing greater concern due to their high levels of production and consumption, along with insufficient degradation in wastewater treatment plants. Pharmaceuticals are continuously introduced into the ecosystem; thus, these contaminants do not have to persist in the ecosystem to produce negative effects on the environment (Hartmann et.al., 1998; Jones et al., 2001; Petrovic et al., 2004; Arslan-Alaton \& Caglayan, 2006). Analgesics/anti-inflammatory drugs such as ibuprofen and diclofenac, carbamazepine and $\beta$-blockers are among the most commonly used medical prescriptions ( Petrovic et al., 2005; Hernando et al., 2006). The project AquaTerra has estimated that three tons of pharmaceuticals per year are discharged into our rivers (Jones et al., 2001; Gros et al., 2007). In many cases, the consequences of the presence of these pharmaceuticals in the environment are not clear; in other cases, the risk is evident. For example, diclofenac affects mammalian kidneys; this drug has also been associated with the disappearance of the white-backed vultures in India and Pakistan (Fent et al., 2006). Fent and colleges also observed that exposure to propranolol affects zooplankton (Fent et al., 2006).

Cyanobacteria are prokaryotes with high morphological complexity and physiological diversity. These organisms have an outstanding capacity to adapt to a wide range of environments and to survive in extreme or highly degraded environments. Certain cyanobacterial species can produce a broad range of bioactive secondary metabolites called cyanotoxins that are potentially toxic to eukaryotic organisms (Carmichael et al., 2001; Codd et al., 2005). The human pressures exerted on water resources, in combination with climate change, promote accelerated eutrophication of water bodies. This process results in an increase in blooms, particularly cyanobacterial blooms, which are frequently toxic. A growing number of blooms dominated by toxic cyanobacteria may result in severe health and environmental problems. The toxins produced by cyanobacteria are primarily hepatotoxic and neurotoxic. Microcystis aeruginosa frequently forms blooms, and microcystin is the most common toxin produced by these cyanobacteria. Microcystin is synthesised in a mixed polyketide synthase/nonribosomal peptide synthetase system called microcystin synthetase (mcy operon), which is also involved in tailoring and transporting microcystin. Tillett and co-workers identified and sequenced the $m c y$ operon, which is a $55-\mathrm{kb}$ sequence that consists of ten open reading frames that are bidirectional transcribed from a central 732-bp intergenic region between $m c y A$ and $m c y D$ (Tillett et al., 2000). Microcystin synthesis is an inducible

Table 1. Oligonucleotides that were used as primers in the semi-quantitative RT-PCR analyses. Oligonucleótidos utilizados como cebadores en el análisis de RT-PCR semicuantitativa.

\begin{tabular}{lccc}
\hline Primers & Sequence $5^{\prime} \rightarrow 3^{\prime}$ & Length & Tm $\left({ }^{\circ} \mathrm{C}\right)$ \\
\hline$R 16 S$ dir & CAAGTCGAACGGGAATCT TC & 20 & 47 \\
$R 16 S$ rev & CTCAAGTACCGTCAGAACTTC & 21 & 45 \\
$m c y D$ dir & GAGCATTAAGGGCTAAATCG & 20 & 45 \\
$m c y D$ rev & CTTGGTTGCTTCATCAACTC & 20 & \\
\hline
\end{tabular}


event that is thought to be controlled by many environmental and nutritional factors. Two of these factors are iron availability and the $C: N$ balance, which regulate the $m c y$ operon through two master transcriptional regulators, Fur (ferric uptake regulator) and NtcA (Martin-Luna et al., 2006; Kuniyoshi et al., 2011).

Currently, how environmental variables influence cyanotoxin production remains unknown. Thus, monitoring and assessing the effects of benzene and of some of the most used pharmaceuticals on microcystin production is of interest. Paracetamol, atenolol, diclofenac and ibuprofen are pharmaceuticals with high levels of production and consumption. The concern is whether the presence of those pharmaceuticals and of one of the more common organic solvents, benzene, which is found in our rivers, might cause an increase in toxin synthesis. Because $M$. aeruginosa PCC 7806 produces a high amount of microcystin per biomass, this cyanobacterium was used to examine the effects of several emerging contaminants and benzene on its toxicity.

\section{MATERIALS AND METHODS}

\section{Growth conditions}

The axenic strain M. aeruginosa PCC 7806, which was provided by the Pasteur Culture Collection (Paris, France), was used in this study. Cells were grown under batch conditions in BG11 media with $2 \mathrm{mM}$ of $\mathrm{NaNO}_{3}$ and continuous agitation at $25^{\circ} \mathrm{C}$. The cyanobacteria were grown with a light intensity of $40 \mu \mathrm{mol}$ of photons $\mathrm{m}^{-2} \mathrm{~s}^{-1}$; the light intensity was measured using a Quantum Sensor photometer (Skye Instruments, SKP 200). The cultures were started with equal aliquots of $0.3 \mathrm{OD}(600 \mathrm{~nm})$, and stress treatments were applied when the cells reached the exponential growth phase (0.6-0.7 OD). Experiments were performed in $250 \mathrm{~mL}$ Erlenmeyer flasks with continuous agitation. Control flasks were maintained under the same conditions as stressed flask. The following concentrations of pharmaceuticals and benzene were added to the cultures at exponential phase:
$200 \mu \mathrm{g} / \mathrm{L}$ ibuprofen; $20 \mu \mathrm{g} / \mathrm{L}$ atenolol; $20 \mu \mathrm{g} / \mathrm{L}$ diclofenac; $27 \mu \mathrm{g} / \mathrm{L}$ and $166 \mu \mathrm{g} / \mathrm{L}$ paracetamol; and $50 \mu \mathrm{g} / \mathrm{L}$ and $100 \mu \mathrm{g} / \mathrm{L}$ benzene. All the pharmaceuticals are water soluble at these concentrations. Aliquots were collected at four days after the addition of the different compounds and then compared with non-stressed cells.

\section{Analytical methods and microcystin quantification}

Chlorophyll $a$ concentrations were determined spectrophotometrically by measuring the absorbance at $650 \mathrm{~nm}$ according to the procedure described by Mackinney (Mackinney, 1941). The pigment was extracted from $1 \mathrm{~mL}$ samples using $80 \%$ methanol with stirring.

Aliquots $(5 \mathrm{~mL})$ were collected, centrifuged for $5 \mathrm{~min}$ at $4000 \mathrm{rpm}$, and frozen at $-20^{\circ} \mathrm{C}$ for microcystin determination. Total intracellular microcystin was determined from 4 extractions, which were performed using $1 \mathrm{~mL}$ of $80 \%$ methanol, $0.1 \%$ trifluoroacetic acid (TFA), and $0.1 \%$ Tween. For each extraction, the samples were stirred for $15 \mathrm{~min}$ and then centrifuged at $4000 \mathrm{~g}$ for $10 \mathrm{~min}$. Next, the extracts were pooled and quantified using a MicroCystest $\mathrm{R}$ kit (Zeulab). Statistical analyses of all the data were performed using Student's test $(p<0.05)$.

\section{Sampling and RNA isolation}

In total, $25 \mathrm{~mL}$ of each culture was harvested by centrifugation at $4000 \mathrm{~g}$ for $4 \mathrm{~min}$ at $4{ }^{\circ} \mathrm{C}$. The manipulation was performed carefully to avoid altering the RNA. Each cell pellet was suspended in $600 \mu \mathrm{L}$ of $50 \mathrm{mM}$ Tris- $\mathrm{HCl}(\mathrm{pH} 8), 100 \mathrm{mM}$ EDTA and $130 \mu \mathrm{L}$ of chloroform and incubated on ice for $3 \mathrm{~min}$ to eliminate external RNases. After removing the buffer by centrifugation at $13000 \mathrm{~g}$ for $5 \mathrm{~min}$ at $4{ }^{\circ} \mathrm{C}$, the cell pellets were frozen in liquid nitrogen and kept at $-80^{\circ} \mathrm{C}$ until RNA isolation was achieved.

RNA was extracted using TRIzol (Invitrogen) and chloroform extractions according to the manufacturer's instructions. In the last extraction, RNA was collected from the aqueous layer and precipitated in isopropanol and liquid 
nitrogen. Then, the RNA pellet was washed twice with $75 \%$ ethanol.

\section{Reverse transcription (cDNA synthesis)}

Total RNA was treated with 40 units of DNase I (Pharmacia) to eliminate the DNA in the samples. The digestions were incubated at $37^{\circ} \mathrm{C}$ for $1 \mathrm{~h}$ in a volume of $100 \mu \mathrm{L}$ using a buffer containing $4 \mu \mathrm{L}$ of $1 \mathrm{M}$ Tris- $\mathrm{HCl}(\mathrm{pH} 7.5)$ and $0.6 \mu \mathrm{L}$ of $1 \mathrm{M}$ $\mathrm{MgCl}_{2}$ in DEPC- $\mathrm{H}_{2} \mathrm{O}$. After digestion, the enzyme was inactivated by phenol acid:chloroform extraction, and RNA was precipitated with absolute ethanol. The result of the digestion was assessed by PCR using primers targeting the $16 \mathrm{~S}$ rRNA gene.

RNA integrity was verified using a $1 \%$ agarose gel, and the concentration was determined by measuring the absorbance at $260 \mathrm{~nm}$ using a NanoVue (GE Healthcare).

A reverse transcriptase enzyme kit was used for the reverse transcription reaction. In total, $1 \mu \mathrm{g}$ of total RNA was diluted with annealing buffer (10 mM Tris-HCl (pH 8), 1 mM EDTA, and $150 \mathrm{mM} \mathrm{KCl}$ ) and mixed with $150 \mathrm{ng}$ of random hexamer primers (Invitrogen Corp.) in a final volume of $10 \mu \mathrm{L}$. The mixture was heated at $85^{\circ} \mathrm{C}$ for $10 \mathrm{~min}$ and then incubated at $50{ }^{\circ} \mathrm{C}$ for $1 \mathrm{~h}$. RNA was reverse transcribed using $200 \mathrm{U}$ of SuperScript ${ }^{\mathrm{TM}}$ (Gibco BRL) in the presence of $2 \mu \mathrm{L}$ of deoxyribonucleoside triphosphate mixture $(2.5 \mathrm{mM}$ each one), $2 \mu \mathrm{L}$ of dithiothreitol $(100 \mathrm{mM})$ and $4 \mu \mathrm{L}$ of the $5 \mathrm{x}$ buffer, adjusting with DEPC- $\mathrm{H}_{2} \mathrm{O}$ to reach a final volume of $20 \mu \mathrm{L}$. Then, the mixture was incubated at $47^{\circ} \mathrm{C}$ for $1 \mathrm{~h}$ and finally heated at $75^{\circ} \mathrm{C}$ for $15 \mathrm{~min}$.

\section{RT-PCR analysis of gene expression}

Semi-quantitative RT-PCR analyses were performed with the obtained cDNA samples. 16S $\mathrm{r} R N A$ ( $r r s$ ) was used as the housekeeping gene, and specific primer sets were designed to amplify both the studied genes and the endogenous reference gene (Table 1). rrs was used to normalise the possible variation in cDNA concentration as described previously (González et al., 2010). The exponential phase of the amplification was estimated by measuring the amount of PCR products
A)

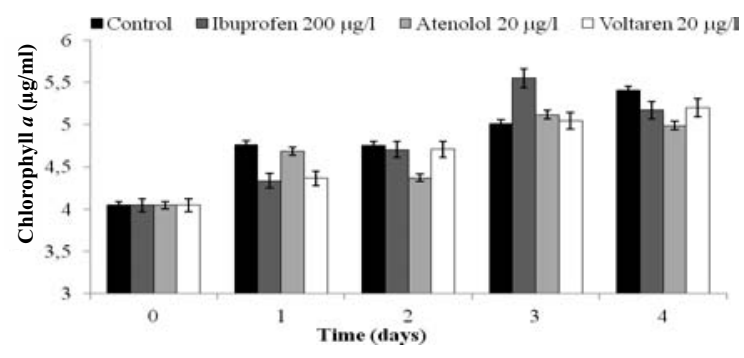

B)

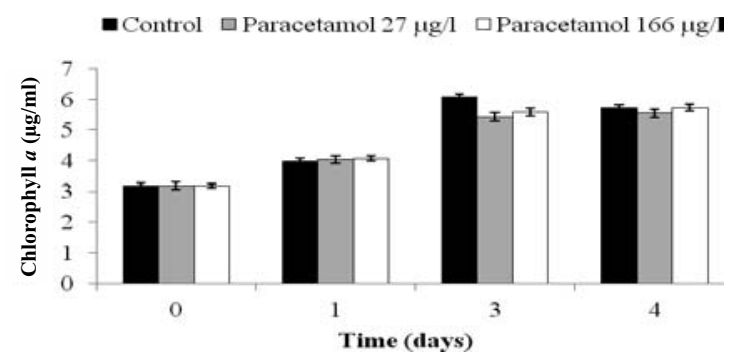

C)

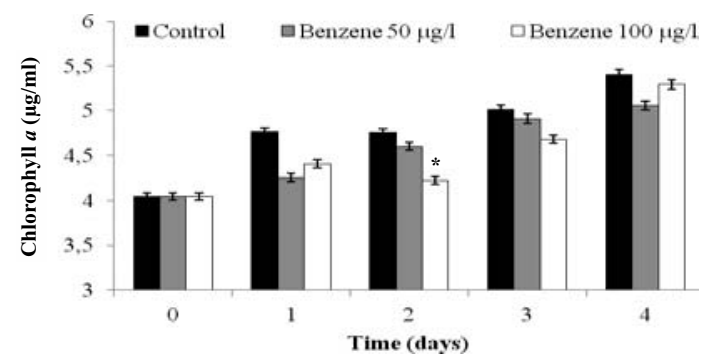

Figure 1. $M$. aeruginosa PCC 7806 growth in the presence of different drugs at their maximum concentrations found in water bodies. The response was estimated using changes in chlorophyll $a$ concentrations. Panel A: Non-stressed cells and ibuprofen $(200 \mu \mathrm{g} / \mathrm{L})-$, atenolol $(20 \mu \mathrm{g} / \mathrm{L})-$ and diclofenac $(20 \mu \mathrm{g} / \mathrm{L})$-treated cells. Panel B: Non-stressed cells and paracetamol $(27 \mu \mathrm{g} / \mathrm{L}$ and $166 \mu \mathrm{g} / \mathrm{L})$-treated cells. Panel C: Nonstressed cells and benzene $(50 \mu \mathrm{g} / \mathrm{L}$ and $100 \mu \mathrm{g} / \mathrm{L})$-treated cells. *A significant decrease $(p<0.05)$ was observed with $100 \mu \mathrm{g} / \mathrm{L}$ of benzene after two days of treatment. Curva de crecimiento de Microcystis aeruginosa PCC7806 en presencia de diferentes fármacos a la concentración maxima disuelta encontrada en aguas. La respuesta fue analizada mediante variaciones de clorofila a. Panel A: células control, células tratadas con ibuprofeno $200 \mu \mathrm{g} / \mathrm{l}$, atenolol $20 \mu \mathrm{g} / \mathrm{l}$ and diclofenac $20 \mu \mathrm{g} / \mathrm{l}$. Panel B: células control, células tratadas con paracetmol a las dos concentraciones estudiadas: $27 \mu \mathrm{g} / \mathrm{y}$ y $166 \mu \mathrm{g} / \mathrm{l}$. Panel C: células control, células tratadas con benceno a las dos concentraciones estudiadas: $50 \mu \mathrm{g} / \mathrm{l}$ and $100 \mu \mathrm{g} /$. *Descenso significativo $(\mathrm{p}<0.05)$ en el segundo día tras el tratamiento con $100 \mu \mathrm{g} / \mathrm{l}$ de benceno.

after different numbers of cycles. That number of cycles was utilised for gene normalisation. 
PCR-amplified DNA fragments were separated by $1 \%$ agarose gel electrophoresis stained with ethidium bromide and analysed using a Gel Doc 2000 Image Analyser (Bio-Rad).

\section{RESULTS}

\section{Effects of benzene, paracetamol, ibuprofen, atenolol, and diclofenac on $M$. aeruginosa PCC7806 growth}

The concentrations of emerging contaminants used in this study were in the upper range or moderately higher (10-20 times) than the concentrations found in some Spanish rivers according to the literature (Barceló \& López, 2007; Gros et al., 2007). The concentration of paracetamol in surface water has a wide range, from $0.1 \mathrm{ng} / \mathrm{L}$ to $2.4 \mu \mathrm{g} / \mathrm{L}$ (Osorio et al. 2012). Ibuprofen and diclofenac are the most concentrated anti-inflammatory drugs, with concentrations up to the $\mathrm{mg} / \mathrm{L}$ range (Osorio et al. 2012). Atenolol contamination can reach values of approximately $0.5 \mathrm{mg} / \mathrm{L}$. Figure 1 shows the changes in chlorophyll $a$ concentrations when cells were grown in the presence of the different contaminants. Panel A shows the small changes in cell growth that were observed in the presence of ibuprofen, atenolol and diclofenac (Voltaren). Panel B reflects the growth observed when two doses of paracetamol were used; no differences in cell growth were observed between the stressed cells and the control cells. Panel C indicates changes in cell growth in the presence of benzene.

Benzene is a well-known, volatile carcinogen that is one of the twenty chemical products with major production. The benzene concentrations studied, $50 \mu \mathrm{g} / \mathrm{L}$ and $100 \mu \mathrm{g} / \mathrm{L}$, were chosen based on levels under specific pollution episodes described in the literature (Hedgecott \& Lewis, 1997; Fernández et al., 2013). However, some industrial effluents, for instance, leachates from dumpsites of an old lindane factory, can reach considerably higher amounts, in the $\mathrm{mg} / \mathrm{L}$ range (Fernández et al., 2013). When $M$. aeruginosa cells were exposed to benzene, their growth was slightly affected during the early days and was significant (Student's test with $p<0.05$ ) on the $2^{\text {nd }}$ day of treatment with $100 \mu \mathrm{g} / \mathrm{L}$ benzene. However, after 4 days, $M$. aeruginosa recovered and reached the same density as that of control cells (Fig. 1C) most likely due to the high volatility of benzene. Microcystis growth curves for at least 3 different samples were analysed; the results are shown in Figure 1.

\section{Effects of benzene, paracetamol, ibuprofen, atenolol, and diclofenac on $m c y D$ expression levels}

The extracted total RNA was reverse transcribed, and RT-PCR was performed with cDNA using the $r r s$ gene $(16 \mathrm{~S})$ as the housekeeping gene. Changes in mRNA levels after 4 days of exposure are shown in Figure 2. The $m c y D$ gene encodes a polyketide synthase that is responsible for incorporating the Adda group, which is involved in the toxicity of the molecule (Nishizawa et al., 2000; Tillett et al., 2000). This gene is the first gene that is transcribed and, therefore, is essential for microcystin synthesis. $m c y D$ expression was slightly induced in cells treated with $50 \mu \mathrm{g} / \mathrm{L}$ diclofenac and benzene compared with that in control cells (Fig. 2A). Nevertheless, mcyD expression decreased in cells grown in the presence of $100 \mu \mathrm{g} / \mathrm{L}$ ibuprofen and benzene (Fig. 2A). In the case of paracetamol, we collected aliquots of cells treated with the highest concentration of paracetamol $(166 \mu \mathrm{g} / \mathrm{L})$ for RNA reverse transcription. When we analysed the gene expression levels in the paracetamol-treated cells, we observed an extreme decrease in transcription levels compared with those of control cells (Fig. 2B).

\section{Microcystin-LR content in treated M. aeruginosa cells}

The levels of Microcystin-LR and the minority D-Aps ${ }^{3}$ MC-LR, which are the only two variants found in this strain (Wiedner et al., 2003), were measured using a MicroCystest $\cap$ kit. This test is based on phosphatase $2 \mathrm{~A}$ inhibition. The results, which are expressed as total microcystinLR equivalents, are represented in Figure 3. The 
obtained results did not show significant changes (Student's test with $p<0.05$ ) in microcystin levels in cells treated with pharmaceuticals. The total microcystin content was slightly decreased in ibuprofen- and Voltaren-treated cells, while the microcystin content in atenolol-treated cells was similar to non-treated cells. Both concentrations of paracetamol showed slightly decreased microcystin content versus control cells.

Figure 3C shows the level of microcystin measured in benzene-treated cells. No significant change $(p<0.05)$ was observed. However, the microcystin contents at both benzene concentrations were slightly lower than control cells after 4 days.

\section{DISCUSSION}

In recent years, significant amounts of substances that have gone unnoticed thus far have been detected. For instance, the Ebro River was studied during years within the framework of the European project AquaTerra (Integrated modelling of the river-sediment-soil-groundwater system). Data from other fluvial systems indicated specific episodes of high levels of emerging contaminants (Hedgecott \& Lewis, 1997; Jurado et al., 2012; Osorio et al., 2012). Wastewater treatment stations were unable to eliminate many of these emerging contaminants; thus, these contaminants flowed into the rivers. Approximately three tons of drugs per year were discharged into the Ebro River; the four pharmaceuticals used in this work were among these drugs (Gros et al., 2007).

Some anti-inflammatory drugs employed in this study, i.e., diclofenac and ibuprofen, are ubiquitous in the affluent of every wastewater treatment plant (EDARs) (Barceló \& López, 2007; Gros et al., 2007). Other drugs, including $\beta$-blockers such as atenolol represent a high percentage of the total contaminants in all EDARs. In addition to wastewaters, atenolol is among the compounds that represent more than $50 \%$ of the total load of the river (Fuerhacker, 2007). Some studies have examined the effect of antibiotics on cyanobacteria; sensitivity to antibiotics has been reported (Holten-Lützhøft et al., 1999; Halling-Sørensen et al., 2000). Notably, the results presented in this work may be influenced by changes in the real concentration exposure. Additionally, our work was performed under laboratory conditions, eliminating the complexity of natural ecosystems. Therefore, with the caution of a laboratory study in a single strain, the results obtained with the chosen concentrations of the pharmaceuticals tested indicated that exposure to these drugs does not significantly affect the
A)

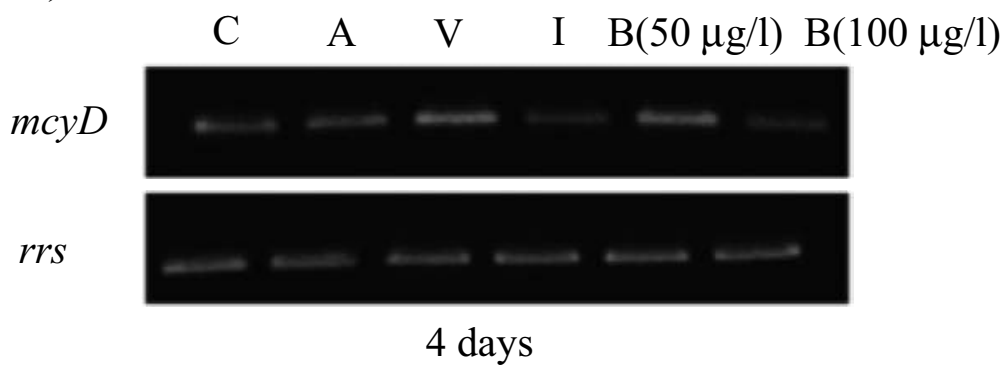

B)

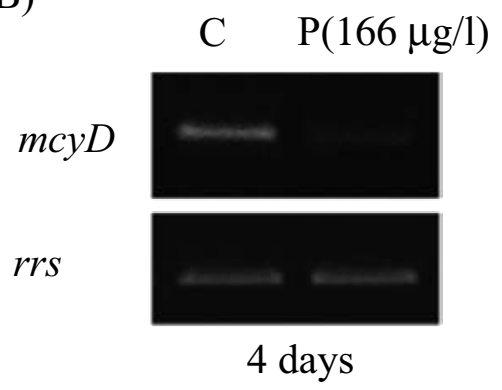

Figure 2. Changes in $m c y D$ expression in $M$. aeruginosa PCC 7806 cells treated with drugs and benzene. $m c y D$ expression was analysed by semi-quantitative RT-PCR. The housekeeping gene $r r s$ was used as a control. Determinations for each gene were performed in the exponential phase of PCR. Panel A: mcyD expression in atenolol (A)-, Voltaren (V)-, ibuprofen (I)- and benzene (B)treated cells and in non-treated cells $(\mathrm{C})$. Panel B: $m c y D$ expression in paracetamol-treated cells $(\mathrm{P})$ compared to that in control cells (C). Cambios en la expression de mcyD en células de Microcystis aeruginosa PCC 7806 tratadas con los distintos fármacos y benceno. La expresión fue estudiada mediante RT-PCR semicuantitativa. Se utilizó el gen rrs como gen de referencia. La determinación de cada gen se llevó a cabo en la fase exponencial de la PCR. Panel A: expresión de mcyD en células control $(C)$ y células tratadas con atenolol (A), voltaren (V), ibuprofeno (I) y benceno (B). Panel B: expresión de mcyD en células control y células tratadas con paracetamol $(P)$. 


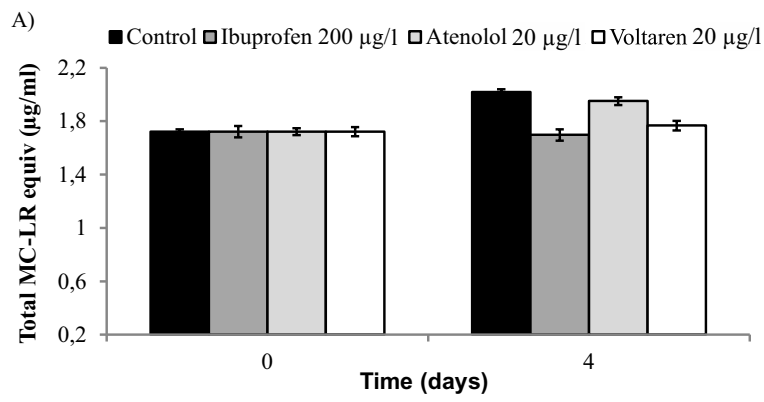

B) $\quad$ Control $\square$ Paracetamol $27 \mu \mathrm{g} / 1 \quad \square$ Paracetamol $166 \mu \mathrm{g} / \mathrm{l}$
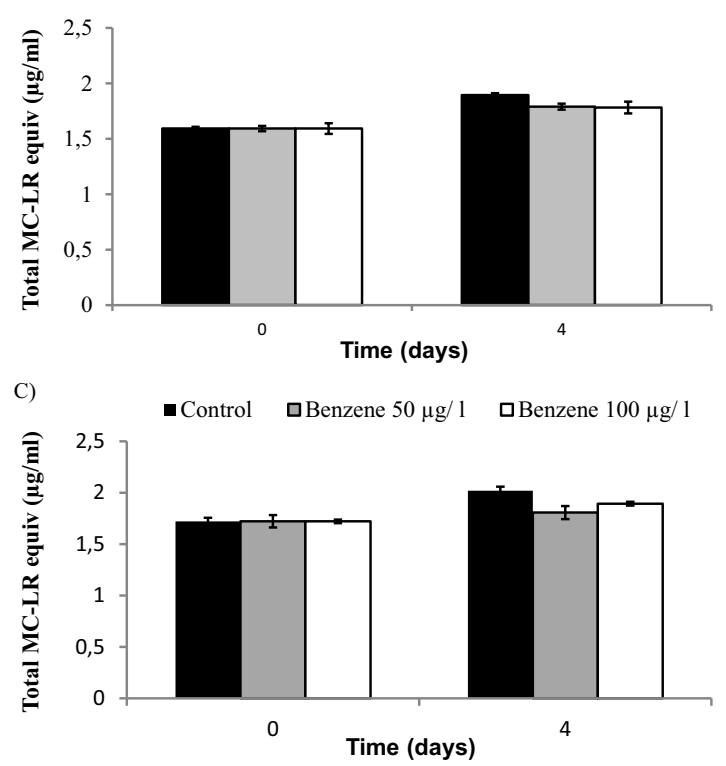

Figure 3. Intracellular microcystin content, which was determined as microcystin-LR equivalents, in stressed cells and in control cells. Panel A: Non-treated cells, ibuprofen (200 $\mu \mathrm{g} / \mathrm{L})$-, atenolol $(20 \mu \mathrm{g} / \mathrm{L})$ - and Voltaren $(20 \mu \mathrm{g} / \mathrm{L})$-treated cells. Panel B: Non-treated cells and paracetamol- $(27 \mu \mathrm{g} / \mathrm{L}$ and $166 \mu \mathrm{g} / \mathrm{L})-$ treated cells. Panel C: Non-treated cells and benzene $(50 \mu \mathrm{g} / \mathrm{L}$ and $100 \mu \mathrm{g} / \mathrm{L}$ )-treated cells. Cantidad de microcistina intracelular expresada en equivalentes de Microcistina-LR presente en las células control y en las células tratadas. Panel A: células control, células tratadas con ibuprofeno $200 \mu \mathrm{g} / \mathrm{l}$, atenolol $20 \mu \mathrm{g} / \mathrm{l}$ and diclofenac $20 \mu \mathrm{g} / \mathrm{l}$. Panel B: células control, células tratadas con paracetamol a las dos concentraciones estudiadas: $27 \mu \mathrm{g} / \mathrm{l}$ y $166 \mu \mathrm{g} / \mathrm{l}$. Panel C: células control, células tratadas con benceno a las dos concentraciones estudiadas: $50 \mu \mathrm{g} / \mathrm{l}$ and $100 \mu \mathrm{g} / \mathrm{l}$.

growth of M. aeruginosa PCC 7806 under these conditions.

Although we observed a slight decrease in cell growth with some of the treatments, no increase in microcystin production was observed. Figures 2 and 3 show that the observed changes in transcriptional levels did not correlate with
microcystin-LR content. We observed a slight reduction in the total amount of toxin in cells treated with ibuprofen and diclofenac. Nonetheless, only ibuprofen lowered gene expression. Intracellular microcystin contents did not exhibit appreciable changes when the cells were treated with benzene; these results are consistent with $m c y D$ expression.

The most remarkable finding was that paracetamol treatment had a slight effect on the growth of Microcystis and was accompanied by an important reduction in $m c y D$ transcription. However, the analysis of the total microcystin content in these cells indicated that a slightly lower amount of toxin was synthesised in these cells than that in control cells.

In summary, no significant changes in growth and microcystin levels were detected in $M$. aeruginosa treated with overdoses of ibuprofen, atenolol, Voltaren, paracetamol and benzene compared with amounts described in natural waters.

\section{ACKNOWLEDGMENTS}

This work was funded by the project 2009/0372 from La CAIXA-Gobierno de Aragón.

\section{REFERENCES}

ARSLAN-ALATON, I. \& A. E. CAGLAYAN. 2006. Toxicity and biodegradability assessment of raw and ozonated procaine penicillin $\mathrm{G}$ formulation effluent. Ecotoxicology and Environmental Safety, 63: 131-140.

BARCELÓ, D. \& M. J. LÓPEZ. 2007. Contaminación y calidad química del agua: el problema de los contaminantes emergentes. En: Panel Científico-Técnico de seguimiento de la política de aguas. Instituto de Investigaciones Químicas y Ambientales-CSIC. Barcelona

CARMICHAEL, W.W., S. M. AZEVEDO, J. S. AN, R. J. MOLICA, E. M. JOCHIMSEN, S. LAU, K. L. RINEHART, G. R. SHAW \& G. K. EAGLESHAM. 2001. Human fatalities from cyanobacteria: chemical and biological evidence for cyanotoxins. Environmental Health Perspectives, 109(7): 663-668. 
CODD, G. A. M., L. F. MORRISON \& J. S. METCALF. 2005. Cyanobacterial toxins: risk management for health protection. Toxicology and Applied Pharmacology, 203(3): 264-272.

FENT, K., A. A. WESTON \& D. CAMINADA. 2006. Ecotoxicology of human pharmaceuticals. Aquatic Toxicology, 76(2): 122-159.

FERNÁNDEZ, J., M. A. ARJOL \& C. CACHO. 2013. POP-contaminated sites from $\mathrm{HCH}$ production in Sabiñánigo, Spain. Environmental Science and Pollution Research, 20: 1937-1950.

FUERHACKER, M. 2007. WFD- can we reach the target? Micropolution and Ecohazard: 17-27.

GONZÁLEZ, A., M. T. BES, F. BARJA, M. L. PELEATO \& M. F. FILLAT. 2010. Overexpression of FurA in Anabaena sp. PCC 7120 reveals new targets for this regulator involved in photosynthesis, iron uptake and cellular morphology. Plant \& Cell Physiology, 51(11): 1900-1914.

GROS, M., M. PETROVIC \& D. BARCELÓ. 2006. Development of a multi-residue analytical methodology based on liquid chromatography-tandem mass spectrometry (LC-MS/MS) for screening and trace level determination of pharmaceuticals in surface and wastewaters. Talanta, 70: 678-690.

GROS, M., M. PETROVIC \& D. BARCELÓ. 2007. Wastewater treatment plants as a pathway for aquatic contamination by pharmaceuticals in the ebro river basin (northeast Spain). Environmental Toxicology and Chemistry, 26(8): 1553-1562.

HALLING-SØRENSEN, B. 2000. Algal toxicity of antibacterial agents used in intensive farming. Chemosphere, 40: 731-739.

HARTMANN, A., A. C. ALDER, T. KOLLER \& R. M. WIDMAR. 1998. Identification of fluoroquinolone antibiotics as the main source of umuC genotoxicity in native hospital wastewater. Environmental Toxicology and Chemistry, 17: 377-382.

HEDGECOTT, S. \& S. LEWIS. 1997. An Update on Proposed Environmental Quality Standards for Benzene. In Water: Final Report to the Department of the Environment. Water Research Centre (Great Britain).

HERNANDO, M. D., E. HEATH, M. PETROVIC \& D. BARCELÓ. 2006. Trace-level determination of pharmaceutical residues by LC-MS/MS in natural and treated waters. A pilot-survey study. Analytical and Bioanalytical Chemistry, 385: 985-991.

HOLTEN-LÜTZHØFT, H. C., B. HALLING-SØRENSEN \& S. E. JØRGENSEN. 1999. Algal toxicity of antibacterial agents applied in Danish fish farming. Arch. Environmental Contamination and Toxicology, 36: 1-6.

JONES, O. A., N. VOULVOULIS \& J. N. LESTER. 2001. Human pharmaceuticals in the aquatic environment a review. Environmental Technology, 22(12): 1383-1394.

JURADO, A., E. VÀZQUEZ-SUÑÉ, J. CARRERA, M. LÓPEZ DE ALDA, E. PUJADES \& D. BARCELÓ. 2012. Emerging organic contaminants in groundwater in Spain: A review of sources, recent occurrence and fate in a European context. Science of The Total Environment, 440: 82-94.

KUNIYOSHI, T. M., A. GONZÁLEZ, S. LOPEZGOMOLLON, A. VALLADARES, M. T. BES, M. F. FILLAT \& M. L. PELEATO. 2011. 2-oxoglutarate enhances NtcA binding activity to promoter regions of the microcystin synthesis gene cluster. FEBS Lettres, 585(24): 3921-3926.

MACKINNEY, G. 1941. Absorption of light by chlorophyll solution. Journal of Biological Chemistry, 140: 315-322.

MARTIN-LUNA, B., J. A. HERNANDEZ, M. T. BES, M. F. FILLAT \& M. L.PELEATO. 2006. Identification of a Ferric uptake regulator from Microcystis aeruginosa PCC7806. FEMS Microbiology Lettres, 254(1): 63-70.

NISHIZAWA, T., A. UEDA, M. ASAYAMA, K. FUJII, K. HARADAM K. OCHI \& M. SHIRAI. 2000. Polyketide synthase gene coupled to the peptide synthetase module involved in the biosynthesis of the cyclic heptapeptide microcystin. Journal of Biochemistry, 127: 779-89.

OSORIO, V., R. MARCÉ, S. PÉREZ, A. GINEBREDA, J. L. CORTINA \& D. BARCELÓ. 2012. Occurrence and modelling of pharmaceuticals on a sewage-impacted Mediterranean river and their dynamics under different hydrological conditions. Science of The Total Environment, 440: 3-13.

PETROVIC, M., E. ELJARRAT, M. J. L. DE ALDA \& D. BARCELÓ. 2004. Endocrine disrupting compounds and other emerging contaminants in the environment: a survey on new monitoring strategies and occurrence data. Analytical and Bioanalytical Chemistry, 378(3): 549-562.

PETROVIC, M., M. HERNANDO, M. S. DÍAZCRUZ \& D. BARCELÓ. 2005. Liquid chromatography-tandem mass spectrometry for the analysis of pharmaceutical residues in environmental samples: a review. Journal of Chromatography A, 1067(1-2): 1-14. 
TILLETT, D., E. DITTMAN, M. ERHARD, H. VAN DÖHREN, T. BÖRNER \& B.A. NEILAN. 2000. Structural organization of microcystin biosynthesis in Microcystis aeruginosa PCC7806: an integrated peptide-polyketide synthetase system. Chemistry \& Biolog., 7(10): 753-764.

VITOUSEK, P. M., J. D. ABER, R. W. HOWARTH, G. E. LIKENS, P. A. MATSON, D. W. SCHINDLER, W. H. SCHLESINGER \& D. G. TILMAN.
1997. Human alteration of the global nitrogen cycle: Sources and consequences. Ecological Applications, 7: 737-750.

WIEDNER, C., P. M. VISSER, J. FASTNER, J. S. METCALF, G. A. CODD \& L. R. MUR. 2003. Effects of light on the microcystin content of Microcystis strain PCC 7806. Applied and Environmental Microbiology, 69(3): 1475-1481. 